\title{
Oxoguanine Glycosylase 1 Protects Against Methamphetamine-Enhanced Fetal Brain Oxidative DNA Damage and Neurodevelopmental Deficits
}

\author{
Andrea W. Wong, ${ }^{1}$ Gordon P. McCallum, ${ }^{1}$ Winnie Jeng, ${ }^{1}$ and Peter G. Wells ${ }^{1,2}$ \\ ${ }^{1}$ Faculty of Pharmacy, and ${ }^{2}$ Department of Pharmacology and Toxicology, University of Toronto, Toronto, Ontario, Canada M5S 2M2
}

\begin{abstract}
In utero methamphetamine (METH) exposure enhances the oxidative DNA lesion 7,8-dihydro-8-oxoguanine (8-oxoG) in $\mathrm{CD}-1$ fetal mouse brain, and causes long-term postnatal motor coordination deficits. Herein we used oxoguanine glycosylase 1 (ogg1) knock-out mice to determine the pathogenic roles of 8-oxoG and OGG1, which repairs 8-0xoG, in METH-initiated neurodevelopmental anomalies. Administration of METH ( 20 or $40 \mathrm{mg} / \mathrm{kg}$ ) on gestational day 17 to pregnant $+/-$ OGG1-deficient females caused a drug dose- and gene dose-dependent increase in 8-oxoG levels in 0GG1-deficient fetal brains $(p<0.05)$. Female ogg1 knock-out offspring exposed in utero to high-dose METH exhibited gene dose-dependent enhanced motor coordination deficits for at least 12 weeks postnatally $(p<0.05)$. Contrary to METH-treated adult mice, METH-exposed CD-1 fetal brains did not exhibit altered apoptosis or DNA synthesis, and OGG1deficient offspring exposed in utero to METH did not exhibit postnatal dopaminergic nerve terminal degeneration, suggesting different mechanisms. Enhanced 8-oxoG repair activity in fetal relative to adult organs suggests an important developmental protective role of OGG1 against in utero genotoxic stress. These observations provide the most direct evidence to date that 8-oxoG constitutes an embryopathic molecular lesion, and that functional fetal DNA repair protects against METH teratogenicity.
\end{abstract}

Key words: methamphetamine; oxoguanine glycosylase (OGG1); oxidative DNA damage; 8-oxoguanine; DNA repair; neurodevelopment

\section{Introduction}

Methamphetamine (METH; "speed," "ice") is an addictive psychomotor stimulant that has been used at least once by $4 \%$ of the U.S. population (National Institute on Drug Abuse Research Report Series, 2002). The neurotoxic effects of METH in adults have been extensively studied (for review, see Cadet et al., 2003), but the consequences of developmental METH exposure in humans and the underlying mechanisms are not well characterized. METH use during pregnancy is associated with numerous adverse effects (Plessinger, 1998; Chang et al., 2004).

METH-initiated neurotoxicity may be mediated by reactive oxygen species (ROS) (for review, see Cadet and Brannock, 1998), which can damage cellular macromolecules or alter signal transduction pathways. The high oxygen consumption and metabolic rate of the brain render it susceptible to ROS-initiated damage. The developing embryo and fetus are particularly vulnerable to oxidative damage because of their low antioxidative capacity (Wells and Winn, 1996; Wells et al., 1997, 2005). Previ-

Received June 5, 2008; accepted July 22, 2008.

This work was supported by a grant from the Canadian Institutes of Health Research (CIHR). A.W.W. was supported by a doctoral award from the Natural Sciences and Engineering Research Council and a Society of Toxicology (SOT) Novartis doctoral fellowship. G.P.M. was supported by a postdoctoral award from the CIHR/Rx\&D Health Research Foundation. W.J. was supported by a doctoral award from the CIHR/Rx\&D Health Research Foundation and an SOT Covance doctoral fellowship. We thank Dr. Tomas Lindahl (Cancer Research UK) and Dr. Christi A. Walter (University of Texas) for generously providing the ogg 1 knock-out mice.

Correspondence should be addressed to Peter G. Wells, Faculty of Pharmacy, University of Toronto, 144 College Street, Toronto, Ontario, Canada M5S 2M2. E-mail: pg.wells@utoronto.ca.

DOI:10.1523/JNEUROSCI.2557-08.2008

Copyright $\odot 2008$ Society for Neuroscience $\quad 0270-6474 / 08 / 289047-08 \$ 15.00 / 0$ ously, we have shown that CD-1 embryos or fetuses exposed in utero to METH have increased levels of the oxidative DNA lesion 7,8-dihydro-8-oxoguanine (8-oxoG) in the brain and liver and postnatally exhibit long-term deficits in motor coordination (Jeng et al., 2005). Unlike adult mice treated with METH (Jeng et al., 2006), striatal dopaminergic nerve terminal degeneration in offspring exposed in utero was not observed, suggesting different mechanisms.

Potential consequences of oxidative DNA damage include mutations and transcriptional delay (Shibutani and Grollman, 1994; Pastoriza-Gallego et al., 2007). Transcriptional delay may contribute to teratogenic effects, because developmental events must occur within a specific time window, and any delays may result in structural or functional abnormalities (Wells et al., 2005). Cell cycle arrest or changes in apoptosis resulting from oxidative DNA damage may also play a role in developmental abnormalities.

Repair of 8-oxoG occurs primarily through the base excision repair pathway, of which the first two steps are catalyzed by oxoguanine glycosylase 1 (OGG1). OGG1 expression and activity have been detected in various adult rodent tissues, including the brain (Verjat et al., 2000). The capacity of OGG1 to remove 8-oxoG may be the key determinant of oxidative DNA damage levels in the brain, because there is an inverse correlation between regional OGG1 activity and corresponding 8-oxoG levels in mouse brain (Cardozo-Pelaez et al., 2000).

OGG1 mRNA expression has been found in the human fetal brain and liver, as well as in the neonatal rat brain (Nishioka et al., 
1999; Verjat et al., 2000). The importance of OGG1 in protecting the developing brain against oxidative insult is suggested by reports that expression and activity are highest in fetal rodent brain and decline with age (Chen et al., 2002; Englander and Ma, 2006; Larsen et al., 2006). We hypothesized that 8-oxoG is a developmentally pathogenic molecular lesion, and that oggl knock-out mice deficient in 8-oxoG repair will be more susceptible to increased oxidative DNA damage and neurodevelopmental deficits resulting from in utero exposure to enhanced formation of ROS, caused by fetal exposure to a single dose of METH (supplemental Fig. S1, available at www.jneurosci.org as supplemental material).

Preliminary reports of this research were presented at the 2004 and 2006 annual meetings of the Society of Toxicology (USA) (Wong et al., 2004; Wong and Wells, 2006).

\section{Materials and Methods}

Chemicals. 8-Hydroxy-2'-deoxyguanosine was obtained from Cayman Chemical, nuclease P1 and Escherichia coli alkaline phosphatase from Sigma-Aldrich, CIP, 24:1:25 (chloroform:isoamyl alcohol:phenol) from Life Technologies and proteinase K from Roche Diagnostics. All other reagents used were of analytical or HPLC grade.

Drugs. Pure racemic (D/L)-METH was provided by the Healthy Environments and Consumer Safety Branch of Health Canada (Ottawa, Ontario, Canada). The identity and absolute purity of (D/L)-METH was determined by diode array detection using a Bio-Rad REMEDi HS system and confirmed by liquid chromatography-mass spectrometry-mass spectrometry.

Mice. Outbred, virgin, 7-week-old CD-1 female and male mice (Charles River Canada) were acclimatized for 1 week before breeding. Ogg1 knock-out mice were generously provided by Dr. Tomas Lindahl (Cancer Research UK, London, UK) through Dr. Christi A. Walter at the University of Texas Health Science Center at San Antonio (San Antonio, TX). Females were housed overnight three to a cage with a male breeder (for ogg1 knock-out mice, heterozygous $(+/-)$ females were housed overnight with a congenic $+/-$ male breeder). The presence of a vaginal plug the next morning was designated as gestational day (GD) 1. Pregnant females were isolated and housed in plastic cages with ground corncob bedding (Beta Chip; Northeastern Products) and maintained in temperature-controlled rooms with a $12 \mathrm{~h}$ light/dark cycle. Food (Laboratory Rodent Chow 5001; Ralston Purina) and tap water were provided ad libitum. All animal studies were approved by the University of Toronto Animal Care Committee in accordance with the standards of the Canadian Council on Animal Care.

Animal treatment. Drugs were dissolved with sterilized $0.9 \%$ saline, and the drug or its vehicle were injected intraperitoneally in a fixed volume of $0.1 \mathrm{ml} / 10 \mathrm{~g}$ body weight. Mice were administered a single dose of METH (20 or $40 \mathrm{mg} / \mathrm{kg}$ ) or $0.9 \%$ saline (vehicle) on GD 17 at $1000 \mathrm{~h}$. For analysis of DNA oxidation and 8-oxoG repair activity, pregnant dams were killed $4 \mathrm{~h}$ after drug treatment and the brains and livers were isolated from both dams and fetuses. Organs were subsequently rinsed in ice-cold $1.15 \% \mathrm{KCl}$ solution, snap-frozen in liquid nitrogen, and stored at $-80^{\circ} \mathrm{C}$ until sampling. Fetal tails were frozen for genotyping. For behavioral studies, dams were allowed to deliver spontaneously, and tail snips were obtained from the offspring for genotyping. The offspring were tested at age $6,8,10$, and 12 weeks. For tyrosine hydroxylase (TH) immunohistochemistry, brains from 12-week-old progeny were isolated and fixed in $10 \%$ formalin until further processing. For analysis of apoptosis, brains were isolated at 6,48 , or $72 \mathrm{~h}$ after drug exposure and fixed in $4 \%$ paraformaldehyde at $4^{\circ} \mathrm{C}$. For bromo-deoxyuridine (BrdU) immunohistochemistry, mice were administered $100 \mathrm{mg} / \mathrm{kg}$ (i.p.) BrdU either 5 or $47 \mathrm{~h}$ after drug exposure. Fetal brains were isolated $1 \mathrm{~h}$ after BrdU exposure and fixed in $4 \%$ paraformaldehyde at $4^{\circ} \mathrm{C}$.

Genotyping. DNA was isolated from fetal or adult tail snips using a standard DNA extraction kit (Sigma-Aldrich). Purified DNA (100-300 ng) was added to a PCR master mix containing $50 \mathrm{~mm} \mathrm{KCl,} 10 \mathrm{~mm}$ Tris- $\mathrm{HCl}, \mathrm{pH} 8.3,2 \mathrm{mM} \mathrm{MgCl}_{2}$, forward and reverse primers, $0.8 \mathrm{~mm}$
dNTPs (deoxynucleoside triphosphates), $0.02 \mathrm{U}$ of Taq polymerase, and $\mathrm{ddH}_{2} \mathrm{O}$. The primers $(0.12 \mu \mathrm{M})$ used to amplify the $500 \mathrm{bp}$ band for the ogg1 gene were ogg1-sense ( $5^{\prime}$-ACTGCATCTGCTTAATGGCC-3') (forward primer), and ogg 1 -antisense (5' -CGAAGGTCAGCACTGAACAG$\left.3^{\prime}\right)$ (reverse primer). The primers $(0.1 \mu \mathrm{M})$ used to amplify the $300 \mathrm{bp}$ band for the ogg1 knock-out gene were neo sense (5'CTGAATGAACTGCAGGACGA-3') (forward primer), and neo antisense $\left(5^{\prime}\right.$-CTCTTCGTCCAGATCATCCT- $\left.3^{\prime}\right)$. The final reaction volume was $45 \mu$ l. Samples were placed in a thermal cycler (Eppendorf Mastercycler Gradient; Eppendorf Scientific) and run under the following conditions: $94^{\circ} \mathrm{C}, 1 \mathrm{~min}$; followed by 30 cycles of $94^{\circ} \mathrm{C}, 1 \mathrm{~min} ; 58^{\circ} \mathrm{C}$, $1.5 \mathrm{~min} ; 72^{\circ} \mathrm{C}, 2 \mathrm{~min}$, and a final extension at $94^{\circ} \mathrm{C}$ for $10 \mathrm{~min}$. PCR samples were combined with a $10 \times$ gel loading buffer $(0.25 \%$ bromophenol blue; $0.25 \%$ xylene cyanol, and $15 \%$ Ficoll type 400 in $\mathrm{ddH}_{2} \mathrm{O}$ ) and loaded onto a $1.5 \%$ agarose gel prepared with $1 \times$ Tris-acetic acidEDTA running buffer and ethidium bromide. The agarose gel was run at a constant $100 \mathrm{~V}$ for $1 \mathrm{~h}$, viewed under UV light, and photographed.

Analysis of methamphetamine-initiated DNA oxidation in oggl knockout mice. Brain and liver were homogenized in $500 \mu \mathrm{l}$ of DNA digestion buffer (100 mm Tris-HCl, pH 8.0, 5 mм EDTA, pH 8.0, 0.2\% SDS, 200 $\mathrm{mm} \mathrm{NaCl})$ and allowed to digest overnight with proteinase $\mathrm{K}(50 \mu \mathrm{g} / \mathrm{ml})$ at $55^{\circ} \mathrm{C}$. DNA was extracted as described previously (Liu and Wells, 1995). Isolated DNA (RNA free) was digested to nucleotides by incubation with nuclease P1, incubated with Escherichia coli alkaline phosphatase, and the resulting deoxynucleoside mixture was filtered and analyzed by HPLC with electrochemical (EC) detection.

Detection of 8-oxo-2' -deoxyguanosine. Oxidation of 2'-dG to 8-oxodG was quantified using an isocratic Series 200 HPLC system (PerkinElmer Instruments) equipped with a $5 \mu \mathrm{m}$ Exsil 80A-ODS C-18 column (5 $\mathrm{cm} \times 4.6 \mathrm{~mm}$; Jones Chromatography), an electrochemical detector (Coulochem II), a guard cell (model 5020), an analytical cell (model 5010) (Coulochem; ESA) and an integrator (PerkinElmer NCI 900 Interface). Samples were filtered $(0.22 \mu \mathrm{m})$, injected into the HPLC-EC system, and eluted using a mobile phase consisting of $50 \mathrm{~mm} \mathrm{KH}_{2} \mathrm{PO}_{4}$ buffer, $\mathrm{pH} 5.5$, methanol $(95: 5, \mathrm{v} / \mathrm{v})$ at a flow rate of $0.8 \mathrm{ml} / \mathrm{min}$ with a detector oxidation potential of $+0.4 \mathrm{~V}$ (Jeng et al., 2005). Chromatographs were analyzed using the TotalChrom chromatography software version 6.2.0 (PerkinElmer Instruments).

Behavioral studies. Mice were conditioned and trained on a constant speed rotarod before performing the motor coordination test. Briefly, mice were required to perch on the stationary rod for $30 \mathrm{~s}$ to accustom them before being allowed to run with a constant speed of $5 \mathrm{rpm}$ for $90 \mathrm{~s}$. Once conditioned, mice were tested at a constant speed of $20 \mathrm{rpm}$. The performance time and speed at which the mice fell from the rod were recorded.

TH immunohistochemistry. Brain sections $(5 \mu \mathrm{m})$ were deparaffinized in xylene and ethanol, followed by a high temperature unmasking in 0.01 M sodium citrate buffer ( $\mathrm{pH}$ 6.0) for $5 \mathrm{~min}$. Tissue sections were blocked for $3 \mathrm{~h}$ with $3 \% \mathrm{BSA}, 20 \mathrm{~mm} \mathrm{MgCl}, 0.3 \%$ Tween 20, and $5 \%$ goat serum in PBS followed by an overnight incubation with the goat anti-rabbit TH primary antibody (1:600; Millipore Bioscence Research Reagents). Sections were incubated with biotinylated goat anti-rabbit IgG reagent (1: 200; Vector Laboratories) for $30 \mathrm{~min}$ at room temperature. To quench endogenous peroxidase activity, slides were incubated in $3 \% \mathrm{H}_{2} \mathrm{O}_{2}$ in methanol for $30 \mathrm{~min}$ at room temperature. Detection was performed using the Vectastain Elite ABC Reagent kit and 3,3'-diaminobenzidine (DAB) kit (Vector Laboratories).

TUNEL histochemistry. Apoptosis was detected using the terminal deoxynucleotidyl transferase-mediated dUTP nick end labeling (TUNEL) assay (Roche Diagnostics). Briefly, sections were deparaffinized and incubated in $20 \mu \mathrm{g} / \mathrm{ml}$ proteinase $\mathrm{K}$ in prewarmed $10 \mathrm{~mm}$ Tris- $\mathrm{HCl}, \mathrm{pH} 7.5$, for $15 \mathrm{~min}$ at $37^{\circ} \mathrm{C}$. Sections were then washed in PBS, covered with TUNEL labeling solution and a layer of Parafilm to prevent dehydration, and incubated for $90 \mathrm{~min}$ at $37^{\circ} \mathrm{C}$. Sections were briefly washed in PBS, then mounted in aqueous mounting media and viewed.

BrdU immunohistochemistry. Sections were incubated in $2 \mathrm{~N} \mathrm{HCl}$ for $45 \mathrm{~min}$ to denature DNA. The acid was neutralized by incubation in 50 $\mathrm{mm}$ Tris base for $10 \mathrm{~min}$. To quench endogenous peroxidase activity, slides were incubated in $3 \% \mathrm{H}_{2} \mathrm{O}_{2}$ in methanol for $30 \mathrm{~min}$ at room 
temperature. Sections were blocked for $3 \mathrm{~h}$ with Mouse on Mouse (M.O.M.) mouse IgG blocking reagent (Vector Laboratories) in PBS, then incubated in M.O.M. diluent (Vector Laboratories) for $5 \mathrm{~min}$. Tissue sections were incubated in a 1:25 dilution of mouse monoclonal anti-BrdU antibody (BD Biosciences) in M.O.M. diluent overnight at $4^{\circ} \mathrm{C}$, followed by incubation with a 1:250 dilution of anti-mouse IgG reagent (Vector Laboratories). Detection was performed using the Vectastain Elite ABC Reagent kit and DAB kit (Vector Laboratories).

8-oxoG repair activity. OGG1 activity was assayed by an oligonucleotide incision assay using as the substrate a double-stranded oligonucleotide containing a single 8-oxoG residue. Briefly, 100 nmoles of a 49-mer oligonucleotide containing a single, internal 8-oxoG residue [5'-TAGACATTGCCATTCTCGATA-8-oxoG-GATCCGGTCAAACCTAGACGAATTCCG-3' (sequence from Klungland et al., 1999); Sigma-Genosys] was labeled at the $3^{\prime}$-terminus with biotin (Pierce Biotechnology). The labeled oligonucleotide was annealed to a twofold molar excess of its complementary sequence (5'CGAATTCGTCTAGGTTTGACCGGATCCTATCGAGAATGGCAATGTCTA-3') with Copposite 8-oxoG, using an annealing buffer $(0.1 \mathrm{M} \mathrm{NaCl}, 10 \mathrm{~mm}$ Tris-HCl, pH 7.4, 1 mм EDTA) and by heating to $95^{\circ} \mathrm{C}$ for $5 \mathrm{~min}$ and then cooling to room temperature.

Nuclear extracts were prepared from adult or fetal (GD 17) brains and livers according to the small-scale procedure described by Lee et al. (1988) with modifications. Briefly, $100 \mathrm{mg}$ tissues samples were homogenized in $1 \mathrm{ml}$ of buffer A (10 mM HEPES, pH 7.9, $1.5 \mathrm{~mm} \mathrm{MgCl}_{2}, 10 \mathrm{~mm}$ $\mathrm{KCl}$, and $0.5 \mathrm{~mm} \mathrm{DTT}$ ) and centrifuged at $1000 \times \mathrm{g}$ for $10 \mathrm{~min}$ at $4^{\circ} \mathrm{C}$. The pellet was resuspended in $140 \mu \mathrm{l}$ of buffer C (20 mM HEPES, pH 7.9, 25\% glycerol, $0.42 \mathrm{M} \mathrm{NaCl}, 1.5 \mathrm{~mm} \mathrm{MgCl}, 0.2 \mathrm{~mm}$ EDTA, $10 \mathrm{~mm} \mathrm{KCl}, 0.5 \mathrm{~mm}$ DTT, and $0.5 \mathrm{~mm}$ PMSF) and mixed gently for $30 \mathrm{~min}$ at $4^{\circ} \mathrm{C}$. The nuclear debris was pelleted by spinning for $10 \mathrm{~min}$ at $14,000 \times \mathrm{g}$, and the supernatant dialyzed against buffer D (20 mM HEPES, pH 7.9, 20\% (v/v) glycerol, 0.1 M KCl, 0.2 mm EDTA, 0.2 mM PMSF, and 0.5 mM DTT) for $4 \mathrm{~h}$ using Slide-A-lyzer Mini Dialysis units (Pierce Biotechnology). The protein concentration was determined by the modified Lowry method described by Markwell et al. (1981), and the nuclear extracts were stored at $-80^{\circ} \mathrm{C}$ before use.

Incision reactions $(20 \mu \mathrm{l})$ contained $25 \mathrm{~mm}$ Tris- $\mathrm{HCl}(\mathrm{pH}$ 7.6), $5 \mathrm{~mm}$ EDTA, $50 \mathrm{~mm} \mathrm{KCl,} 100 \mathrm{fmol}$ of biotin-labeled oligonucleotide duplex, and $20 \mu \mathrm{g}$ of nuclear protein [or purified formamidopyrimidine glycosylase (Fpg) enzyme ( $2 \mathrm{U}$; Trevigen) ] as a positive control. The reactions were incubated for $2 \mathrm{~h}$ at $37^{\circ} \mathrm{C}$ and terminated by the addition of $0.8 \mu \mathrm{l}$ of both $5 \mathrm{mg} / \mathrm{ml}$ proteinase $\mathrm{K}$ and $10 \% \mathrm{SDS}$, followed by incubation at $55^{\circ} \mathrm{C}$ for $15 \mathrm{~min}$. DNA was ethanol precipitated by the addition of $1 \mu \mathrm{g}$ of glycogen and $5.9 \mu \mathrm{l}$ of $7.5 \mathrm{M}$ ammonium acetate and $60 \mu \mathrm{l}$ of ethanol. The dried DNA pellet was resuspended in loading buffer [ $80 \%$ formamide, 50 mм Tris-borate, 1 mм EDTA, pH 8.0, 0.1\% cyanol (w/v), 0.1\% bromophenol blue $(\mathrm{w} / \mathrm{v})]$ and resolved by denaturing electrophoresis in a $15 \%$ polyacrylamide (19:1) gel containing $8.3 \mathrm{M}$ urea. After electrophoresis, samples were transferred $(80 \mathrm{~V} ; 1 \mathrm{~h})$ in $50 \mathrm{~mm}$ Tris-borate, $\mathrm{pH} 8.3,1 \mathrm{~mm}$ EDTA buffer to a Biodyne B nylon membrane (Pall Life Sciences) using a Mini Trans-Blot electrophoretic transfer cell (Bio-Rad). DNA was crosslinked to the membrane using a GS Gene Linker UV chamber (Bio-Rad), set at program mode C-L $(125 \mathrm{~mJ})$. Biotin-labeled DNA was detected using a Phototope-Star detection kit (New England Biolabs) as per the manufacturer's instructions.

Quantification of immunohistochemical and 8-oxoG incision activity data. Determination of DNA synthesis was performed by counting the number of BrdU-stained cells in coronal brain sections. One coronal section was used for measurements in each fetal brain sample, and nine fields within the caudate-putamen were analyzed bilaterally. Each field was analyzed three times, and an average value was calculated.

Band intensities for 8-oxoG incision activity were quantified by densitometry using NIH Image (Scion version Beta 4.02). The mean integrated band densities were calculated by averaging three measurements from each sample. The percentage of cleaved product was calculated by dividing the mean integrated density of the cleaved product band by the sum of the mean integrated densities of the cleaved product and substrate bands.

Statistical analysis. Statistical significance of differences between paired data were determined by the two-tailed Student's $t$ test, whereas

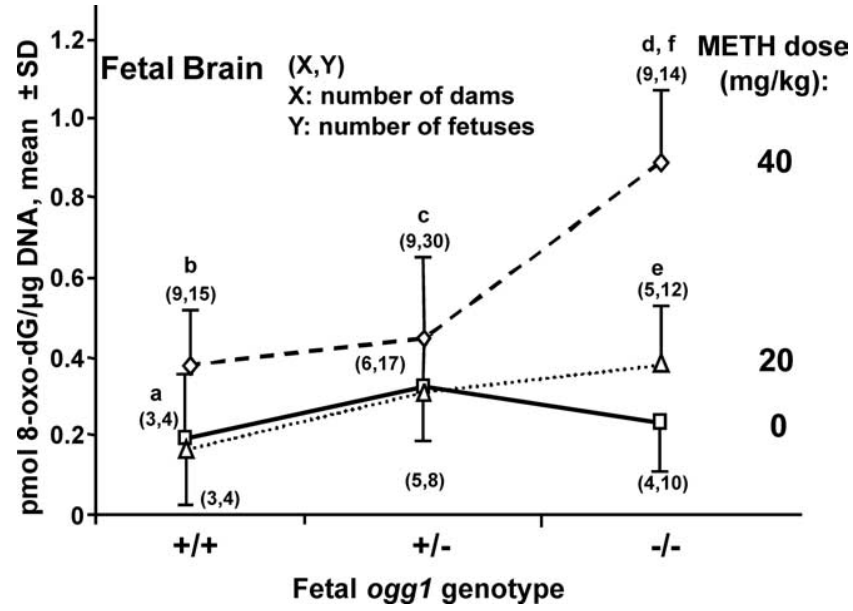

Figure 1. Oxidative DNA damage is increased in OGG1-deficient fetal brains after in utero exposure to METH. METH was dissolved in $0.9 \%$ saline and administered in a single dose ( 20 or $40 \mathrm{mg} / \mathrm{kg}$, i.p.) on GD 17 to pregnant $0 g \mathrm{~g} 1+/-$ dams mated with $+/-$ males. Saline vehicle was used as the control. The dams were killed $4 \mathrm{~h}$ after injection; tissue was isolated from fetal brain and analyzed for oxidative DNA damage reflected by the formation of 8-0xoG. ${ }^{a} p<0.01$ indicates a difference between $+/+$ and $-/-$ fetal brains exposed to $20 \mathrm{mg} / \mathrm{kg}$ METH. ${ }^{\mathrm{b}} p<$ 0.001 indicates a difference between $+/+$ and $-/-$ fetal brains exposed to $40 \mathrm{mg} / \mathrm{kg} \mathrm{METH}$. ${ }^{c} p<0.001$ indicates a difference between $+/-$ and $-/-$ fetal brains exposed to $40 \mathrm{mg} / \mathrm{kg}$ METH. ${ }^{d} p<0.001$ indicates a difference between 40 and $20 \mathrm{mg} / \mathrm{kg} \mathrm{METH}$ in $-/-$ fetal brains. $\mathrm{e}_{p}<0.01$ indicates a difference between $20 \mathrm{mg} / \mathrm{kg}$ METH and the corresponding saline control in $-/-$ fetal brains. ${ }^{f} p<0.0001$ indicates a difference between $40 \mathrm{mg} / \mathrm{kg} \mathrm{METH}$ and the corresponding saline control in $-/-$ fetal brains. $(X, Y)$ indicate the number of dams $(X)$ and fetuses $(Y)$ analyzed. Fetuses were selected randomly and evenly from among the litters.

multiple comparisons among groups were analyzed by one-way ANOVA with a subsequent Tukey's test (GraphPad Prism version 3.02; GraphPad Software). The level of significance was determined to be at $p<0.05$.

\section{Results}

\section{DNA oxidation is increased in METH-exposed fetal brain in} ogg1 knock-out mice

In fetal brain, there were no significant differences in DNA oxidation among saline-exposed wild-type, $(+/+)$ OGG1-normal, heterozygous $(+/-)$ fetuses or homozygous null, (-/-) OGG1deficient fetuses (Fig. 1). However, with low-dose METH exposure, an $80 \%$ increase in 8 -oxoG levels in $+/$ - OGG1-deficient fetuses compared with $+/+$ OGG1-normal littermates and a doubling in DNA oxidation in $-/-$ versus $+/+$ fetuses $(p<$ 0.01 ) were observed. DNA damage was also elevated in fetal brain from METH-exposed $-1-$ fetuses compared with salineexposed controls of the same genotype $(p<0.01)$. Compared with low-dose exposure, high-dose exposure to METH greatly enhanced DNA damage in $-/-$ fetal brains $(p<0.001)$. With high-dose METH exposure, there was a 2.3-fold increase in DNA oxidation in $-/-$ compared with $+/+$ fetuses $(p<0.001)$ and a doubling in 8 -oxoG levels in $-/-$ versus $+/-$ fetuses $(p<$ 0.001 ). Additionally, DNA oxidation was 3.6 -fold higher in METH-exposed compared with saline-exposed $-/-$ fetal brains $(p<0.0001)$.

\section{No increase in fetal liver DNA oxidation levels in METH- exposed ogg1 knock-out mice}

In fetal liver, no significant gene dose-dependent differences in DNA oxidation were observed among saline-exposed $+/+$, $+/-$, or $-/-$ littermates, nor among METH-exposed fetuses of different $o g g 1$ genotypes (supplemental Fig. S2, available at www.jneurosci.org as supplemental material). A drug dose- 
dependent increase in oxidative DNA damage was observed in the fetal liver from $+/+,+/-$, and $-/-$ fetuses exposed to high-dose METH compared with saline-exposed controls of the same genotype $(p<0.01, p=0.01$, and $p<0.05$, respectively).

Enhanced motor coordination deficits in female ogg1 knock-out offspring exposed to high-dose METH in utero Female ogg1 -/- offspring exposed in utero to $40 \mathrm{mg} / \mathrm{kg}$ METH had a shorter latency to fall compared with salineexposed controls of the same genotype at 6,8 and 10 weeks postnatally $(p=0.02$, $p=0.001$, and $p<0.05$, respectively) (Fig. 2 , top). Long-term deficits were also observed in female $-/-$ mice compared with $+/+$ littermates at 8,10 , and 12 weeks $(p<0.001, p<0.01$, and $p<0.01$, respectively) and compared with $+1-$ littermates at 6 and 8 weeks $(p<0.05$ and $p<$ 0.01 , respectively). Among untreated offspring, males appeared to have a shorter latency than females, but this difference was not statistically significant.

\section{No differences in motor coordination deficits in ogg1 knock-out mice exposed to low-dose METH in utero}

Mice exposed in utero to the lower dose $(20 \mathrm{mg} / \mathrm{kg})$ of METH did not have a shorter latency to fall compared with saline-exposed mice (supplemental Fig. S3, available at www.jneurosci.org as supplemental material). Additionally, the latency to fall in $-1-$ OGG1-deficient mice was not significantly different from heterozygous or wild-type mice.

Absence of striatal dopaminergic nerve terminal degeneration in adult ogg1 knock-out offspring exposed to METH in utero Brain sections from 12-week-old mice that were exposed in utero to METH on GD 17 were stained for TH indicative of dopaminergic nerve terminals. Unlike in adult mice treated with METH (Jeng et al., 2006), there was no evidence of postnatal structural degeneration of nerve terminals after in utero METH exposure in OGG1-deficient mice compared with wild-type littermates, nor compared with saline controls (supplemental Fig. S4, available at www.jneurosci.org as supplemental material).

\section{No changes in apoptotic cell death in fetal CD-1 brain after in utero METH exposure}

Levels of apoptosis in the fetal brain were not altered by prenatal exposure to low- or high-dose METH, as determined by TUNEL histochemistry conducted at 6,48 , or $72 \mathrm{~h}$ after exposure (supplemental Fig. S5, available at www.jneurosci.org as supplemental material).

\section{Increased DNA synthesis in fetal brain after in utero METH exposure}

Although no DNA replication activity was detected in the striatum at the time points examined ( 6 and $48 \mathrm{~h}$ ), activity was observed in regions immediately surrounding the lateral ventricle. Exposure to low- or high-dose METH did not significantly alter
DNA synthesis activity in this region $48 \mathrm{~h}$ after exposure (Fig. 3). However, low-dose METH exposure resulted in elevated levels of DNA synthesis in the hippocampus $(p<0.05)$, and increasing the METH dose to $40 \mathrm{mg} / \mathrm{kg}$ led to a decrease in DNA replication compared with low-dose exposure. No changes in DNA synthesis were observed at $6 \mathrm{~h}$ after exposure (data not shown).

Elevated 8-oxoG repair activity in fetal brain and liver relative to adult tissue

8-OxoG incision activity was detected in nuclear extracts from the liver and brain of adult wild-type mice, but minimal activity was observed in adult ogg1 knock-out mice (Fig. 4). OGG1 appears to be the sole contributor to 8-oxoG repair in GD 17 fetal brain and liver nuclear extracts with the complete absence of the incision product in ogg1 knock-out mice (Fig. 5) (limit of detection $<0.12 \mathrm{fmol}$ of labeled probe). Rates of 8-oxoG incision activity were comparable in fetal brain and liver nuclear extracts and approximately two fold higher than those observed in adult tissues (Fig. 6).

\section{Discussion}

The results from this study provide the first evidence for increased susceptibility of $\operatorname{ogg} 1$ knock-out fetuses to the toxicity of ROS-initiating xenobiotics, directly implicating oxidative DNA damage and 8-oxoG in the pathogenic mechanism of METH teratogenicity. These results also suggest that functional repair of oxidative DNA damage in the fetus is important in protecting against METH-initiated neurodevelopmental deficits. Enhanced rates of 8-oxoG repair in fetal compared with adult tissues, together with the complete lack of repair in fetal ogg1 knock-out nuclear extracts, suggest a critical developmental role for OGG1 in protecting the fetus against insults that stimulate in utero oxidative stress. The absence of METH-initiated apoptotic changes 


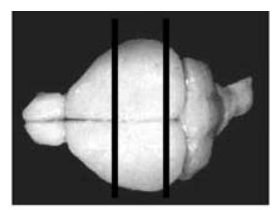

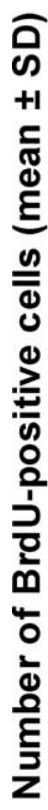

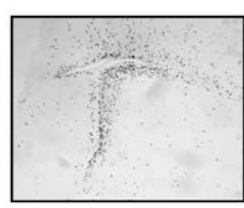

Section 1

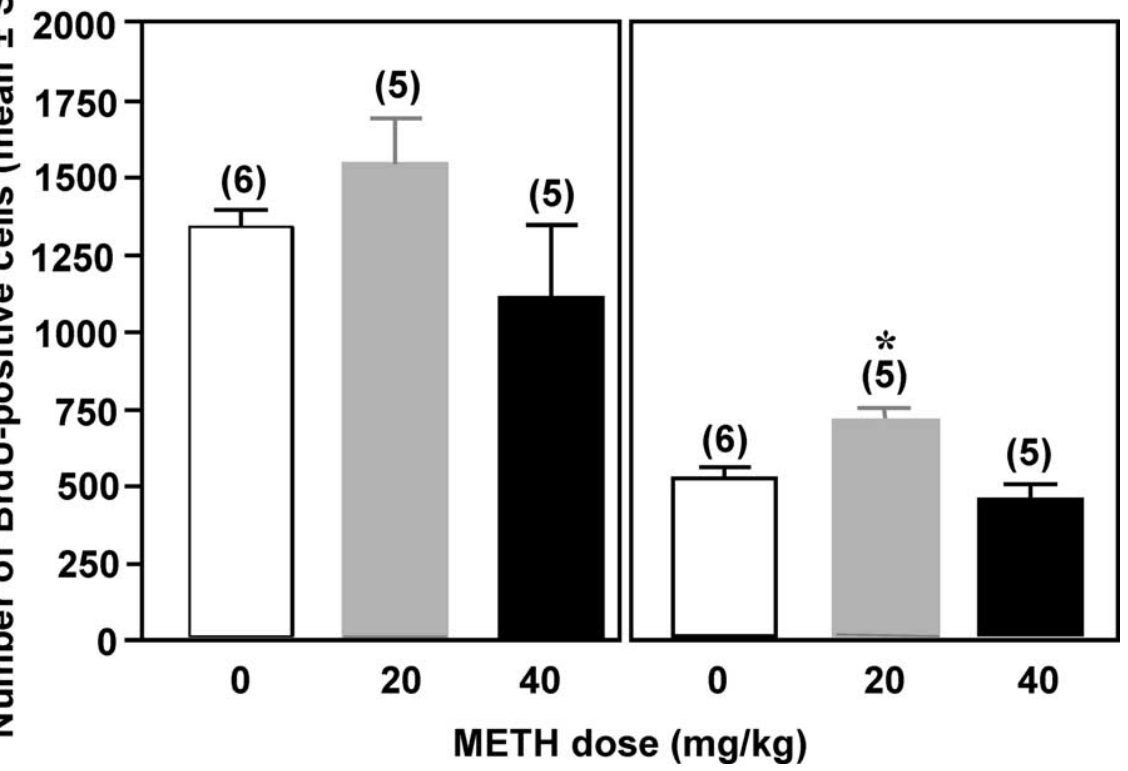

Figure 3. Increased DNA synthesis in CD-1 fetal brain $48 \mathrm{~h}$ after METH exposure. METH (40 or $20 \mathrm{mg} / \mathrm{kg}$ ) or its saline control was administered on GD 17 to pregnant CD-1 mice. At $47 \mathrm{~h}$ after exposure, dams were treated with $100 \mathrm{mg} / \mathrm{kg}$ BrdU. Mice were killed $1 \mathrm{~h}$ after BrdU treatment, and fetal brain sections were assessed for BrdU, indicative of DNA replication activity. Representative coronal sections of GD 17 fetal brain in the area surrounding the lateral ventricle and hippocampus are shown in sections 1 and 2 , respectively. ${ }^{*} p<0.05$ indicates a difference from saline control and from $40 \mathrm{mg} / \mathrm{kg} \mathrm{METH}$. Immunohistochemical staining was assessed at $200 \times$ magnification with a minimum of $n=5$ per treatment group. One coronal section was used for measurements in each fetal brain sample, and nine fields within the caudate-putamen were analyzed bilaterally. Each field was analyzed three times, and an average value was calculated. Fetuses were selected randomly and evenly from different litters. No differences in DNA replication were observed at $6 \mathrm{~h}$ after METH exposure (data not shown).

or dopaminergic nerve terminal degeneration in fetal brain suggest substantial differences between the mechanisms underlying METH-initiated neurodevelopmental deficits in the fetus and neurodegeneration after METH administration to adults.

A potential reason for these differences may be lower levels of dopamine in fetal brain. Mice are born with $\sim 20 \%$ of the dopamine that is observed in adult brain (Agrawal et al., 1968; Alhava and Klinge, 1972). Early studies indicated that developing mice are more resistant to lethal doses of amphetamine than adults (Alhava, 1972, 1975). More recent work in rats has shown that weanling rats are resistant to losses of TH-immunoreactivity and dopamine depletion in the caudate-putamen after methamphetamine (Pu and Vorhees, 1993; Cappon et al., 1997) or amphetamine (Bowyer, 2000) treatment. This observed resistance may be attributable in part to a blunted hyperthermic response in young rats because the severity of METH-induced neurotoxicity correlates with the degree of hyperthermia induced by treatment in the adult rat with sustained elevations in core temperature between 39.5 to $41^{\circ} \mathrm{C}$ required to observe dopamine-terminal degeneration in the striatum (Bowyer et al., 1994; Bowyer and Holson, 1995). The studies of Cappon et al. (1997) point out a developmental distinction between METH response and hyperthermia between postnatal day 20 (P20) and P40 rats. Both P20 and $\mathrm{P} 40$ rats are resistant to $\mathrm{METH}$-induced hyperthermia, neostriatal dopamine depletion, and elevations in glial fibrillary acidic protein content when dosed at an ambient temperature of $22^{\circ} \mathrm{C}$. However, raising the ambient temperature to $30^{\circ} \mathrm{C}$ restores an adult pattern of response in $\mathrm{P} 40$ rats but not in P20 rats despite a comparable hyperthermic response. It is possible that pregnancy itself affords some protection to the developing fetus against METH neurotoxicity through altered thermoregulatory responses, given reports of neuroimmune hyporesponsiveness in late gestation (Martin et al., 1995; Spencer et al., 2008).

8-OxoG formation in dividing developing neurons may lead to transversion mutations, which can affect the expression and activity of proteins required for normal neuronal development and function. In addition to these effects, the 8-oxoG lesion may alter gene transcription via several potential mechanisms. Conflicting evidence exists regarding the ability of 8-oxoG or 8-oxoG-derived G:C to T:A transversions to disrupt the function of RNA polymerase II. Stalling of basal transcriptional machinery by the introduction of 8-oxoG lesions to the DNA template has been observed (Viswanathan and Doetsch, 1998), but other studies suggest that only DNA helix-distorting changes (singlestrand breaks, pyrimidine dimers) and not oxidized bases may be capable of blocking DNA and RNA polymerases (Kathe et al., 2004). These experimental discrepancies may be explained by recent observations that the repair level and/or the transcriptional arrest caused by a unique 8-oxoG lesion varies according to the promoter strength and nucleotidic sequence surrounding the lesion (Pastoriza-Gallego et al., 2007). Transcriptional mutagenesis via 8 -oxoG bypass has been documented in mammalian systems (Charlet-Berguerand et al., 2006), and this mechanism has been shown to lead to phenotypic changes in bacterial systems (Viswanathan et al., 1999). 8-OxoG lesions may also effect the expression of specific genes via their ability to regulate the binding efficiency of transcription factors such as nuclear factor $\kappa \mathrm{B}$ $(\mathrm{NF}-\kappa \mathrm{B})$ to specific promoter elements (Hailer-Morrison et al., 2003).

Accumulation of oxidative DNA damage can also lead to apoptosis; however, there was no evidence for METH-initiated alterations in developmental apoptosis at various time points after in utero exposure in CD-1 mice, which are more susceptible to the teratogenic effects of METH than B6/129SV mice (the background strain of the $\operatorname{ogg} 1$ knock-out mice). This is in stark contrast to previous studies conducted in adults, in which METH treatment resulted in apoptotic cell death in various brain regions (for review, see Cadet et al., 2003), and suggests that apoptosis is not involved in the mechanism of METH-initiated neurodevelopmental deficits.

Oxidative DNA damage may also trigger cell cycle arrest in cycling cells, allowing time for repair of damage to occur before DNA is replicated. However, DNA synthesis was enhanced in the hippocampus of CD-1 fetuses after low-dose exposure to METH. 


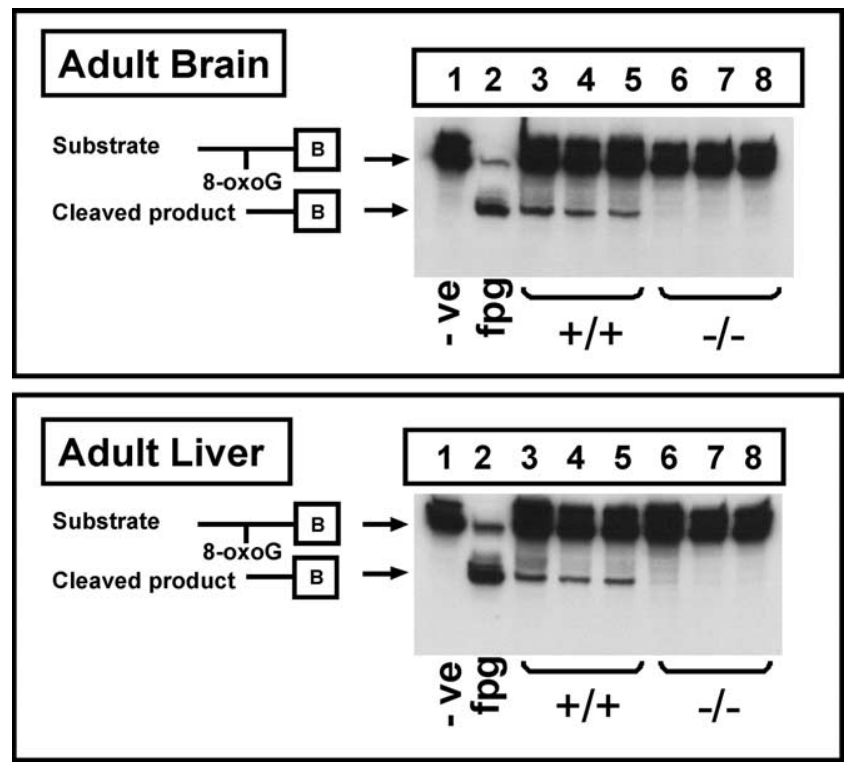

Figure 4. Endogenous 8-0xoG repair activity in adult brain and liver nuclear extracts from ogg 1 knock-out mice. Extracts were incubated with a biotin-labeled oligonucleotide containing 8-oxoG that was annealed to its complementary strand containing Copposite 8-oxoG. Reaction products were resolved by 15\% PAGE. Lane 1 negative control, $100 \mathrm{fmol}$ of oligonucleotide incubated with no nuclear extract. Lane 2 positive control, $100 \mathrm{fmol}$ of oligonucleotide incubated with Fpg (2 U), the bacterial functional homolog of OGG1. Lanes 3-5, $100 \mathrm{fmol}$ of oligonucleotide incubated with $20 \mu \mathrm{g}$ of nuclear extract from adult brain or liver from ogg 1 wildtype $(+/+)$ mice. Lanes $6-8,100 \mathrm{fmol}$ of oligonucleotide incubated with $20 \mu \mathrm{g}$ of nuclear extract from adult brain or liver from ogg 1 homozygous-null $(-/-)$ mice.

Because this was not observed after high-dose METH exposure, it is unlikely that changes in DNA synthesis contribute to METHinitiated neurodevelopmental deficits.

The lack of striatal dopaminergic terminal degeneration in adult ogg1 knock-out mice exposed in utero to METH indicates that protection by OGG1 against neurodevelopmental deficits may occur via a mechanism other than preventing the degeneration of dopaminergic nerve terminals that occurs in adult mice treated with METH. We confirmed in CD-1 mice that the mechanism underlying METH-initiated neurodevelopmental deficits is different from that involved in adult neurotoxicity by demonstrating that terminal degeneration did not occur at earlier stages after METH exposure, with subsequent recovery by adulthood (data not shown). Instead, these deficits may involve altered proteins or delayed expression of proteins that affect axonal migration, dendritic branching, and synaptogenesis.

The increase in oxidative DNA damage in fetuses exposed to $40 \mathrm{mg} / \mathrm{kg}$ versus $20 \mathrm{mg} / \mathrm{kg} \mathrm{METH}$, as well as the lack of postnatal functional deficits in $-/-$ ogg 1 knock-out mice exposed to lowdose METH, indicate that protection provided by OGG1 is drug dose-dependent. The higher dose used in this study results in a peak METH concentration in the GD 14 mouse brain that is similar to brain levels observed in premature infants born to METH-abusing mothers (Bost et al., 1989; Won et al., 2001), indicating that the results from this study may be relevant to human use. Although low-dose METH did not cause motor coordination deficits measurable by the rotarod test, 8-oxoG levels were enhanced in OGG1-deficient mice, and it is possible that additional types of functional deficits including cognitive anomalies may be caused by this dose, as well as by the higher dose used in this study. If so, the extent to which the 8-oxoG lesion contributes to such deficits would need to be determined. Additionally,
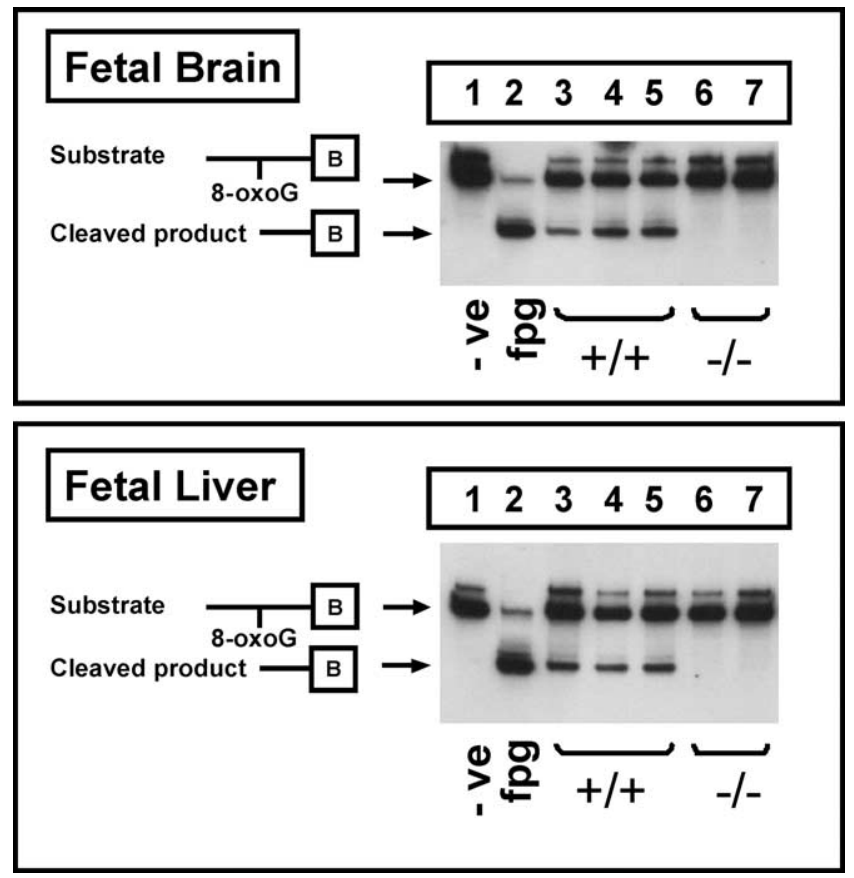

Figure 5. Endogenous 8-0xoG repair activity in fetal brain and liver nuclear extracts from ogg 1 knock-out mice. Extracts were incubated with a biotin-labeled oligonucleotide containing 8-oxoG that was annealed to its complementary strand containing Copposite 8-0xoG. Reaction products were resolved by 15\% PAGE. Lane 1 negative control, $100 \mathrm{fmol}$ of oligonucleotide incubated with no nuclear extract. Lane 2 positive control, $100 \mathrm{fmol}$ of oligonucleotide incubated with $\mathrm{Fpg}(2 \mathrm{U})$, the bacterial functional homolog of $0 \mathrm{GG1}$. Lanes 3-5, $100 \mathrm{fmol}$ of oligonucleotide incubated with $20 \mu \mathrm{g}$ of nuclear extract from GD 17 brain or liver from ogg 1 wildtype $(+/+)$ fetuses from different litters. Lanes $6,7,100 \mathrm{fmol}$ of oligonucleotide incubated with $20 \mu \mathrm{g}$ of nuclear extract from GD 17 brain or liver from ogg 1 homozygous-null (-/-) fetuses from different litters.

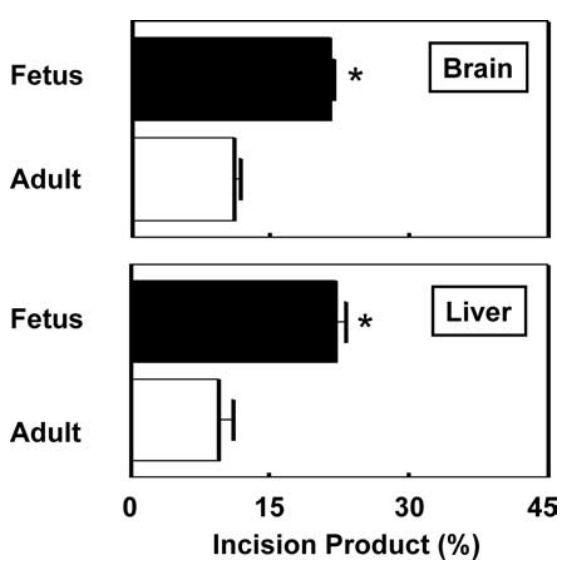

Figure 6. Densitometric analysis of endogenous fetal versus adult 8-0xoG repair activity in nuclear extracts from ogg1 wild-type $(+/+)$ mice. Extracts were incubated with a biotinlabeled oligonucleotide containing 8-0X0G that was annealed to its complementary strand containing Copposite 8-0xoG. Oligonucleotide ( $100 \mathrm{fmol}$ ) was incubated with $20 \mu \mathrm{g}$ of nuclear extract from GD 17 brain or liver ( $n=5$; mean \pm SD) or adult brain or liver $(n=3$; mean \pm SD). Fetuses were selected randomly and evenly from different litters. ${ }^{*} p<0.05$ indicate a difference from the same tissue from adults.

other structural and functional anomalies may result from exposure to METH over a broader gestational period compared with the single dose used in this study.

Protection by OGG1 against both oxidative DNA damage in fetal brain and postnatal neurodevelopmental deficits was also gene dose-dependent, because $-/-$ mice were more susceptible 
to METH-enhanced oxidative DNA damage compared with $+/-$ mice, which in turn exhibited a motor coordination deficit generally between that of the $+/+$ and $-/-$ offspring, although the $+/$ - offspring were not statistically different from $+/+$ littermates. It appears that both copies of OGG1 may be necessary to provide maximal protection against ROS-initiating teratogens like METH.

The increased susceptibility to oxidative DNA damage observed in the fetal brain but not fetal liver of $\operatorname{ogg} 1$ knock-out mice exposed to METH despite comparable 8-oxoG repair activity may reflect differences in ROS formation and/or activity of antioxidative enzymes in these tissues. An additional contributing factor could be greater ROS formation in the brain secondary to monoamine metabolism. In regard to ROS formation, we have shown that one of the isoforms of prostaglandin $\mathrm{H}$ synthase (PHS-2), which is constitutively expressed in brain but not liver, can bioactivate METH to free radical intermediates capable of producing ROS-initiated formation of 8 -oxoG in adult brain (Jeng et al., 2006).

In the present study, 8-oxoG repair activity was found to be approximately twofold higher in fetal tissues compared with those of adults, which is consistent with previous observations in both rat and mouse (Chen et al., 2002; Riis et al., 2002; Englander and Ma, 2006; Larsen et al., 2006). The complete lack of incision product observed in fetal tissues suggests that OGG1 is the sole contributor to 8-oxoG repair in GD 17 brain and liver nuclear extracts, and that the Nei-like DNA repair glycosylases (NEIL1/ $2 / 3$ ), which have low in vitro repair capacity against 8-oxoG (Rosenquist et al., 2003), do not appear to contribute measurably to 8-oxoG removal in these gestational tissues during the fetal period of development.

Less direct evidence implicating oxidative DNA damage and repair in the mechanism of teratogenesis includes the enhanced susceptibility of $p 53$ and atm knock-out mice, which lack key proteins for detecting and/or repairing oxidative DNA damage, to the embryopathic and teratogenic effects of various ROSinitiating agents (Moallem and Hales, 1998; Laposa et al., 2004; Bhuller et al., 2006; Bhuller and Wells, 2006). In humans, it has recently been suggested that polymorphisms in DNA repair genes, including ogg1, may be involved in teratogenesis (Olshan et al., 2005).

Although little is known about the effects of oxidative DNA damage in the developing fetal brain, there is evidence of roles for 8 -oxoG in contributing to neurodegeneration in adults. For example, METH-initiated dopaminergic nerve terminal degeneration and motor coordination deficits in adult mice are associated with localized increases in 8-oxoG levels in particular brain regions, all of which are inhibited by pretreatment with a single dose of Aspirin (acetylsalicylic acid), an inhibitor of the enzyme prostaglandin $\mathrm{H}$ synthase thought to catalyze METH bioactivation to a neurotoxic free radical intermediate (Jeng et al., 2006). Genes involved in DNA repair, including those of the base excision repair pathway, are upregulated in mice after METH administration, suggesting increased repair activity may counteract METH-induced oxidative DNA damage (Cadet et al., 2002). Additionally, the finding that more DNA repair genes are upregulated in wild-type mice than in c-fos-deficient mice, which are more susceptible to the toxic effects of METH, suggests that the inability to trigger DNA repair responses contributes to the increased sensitivity of these mice to the drug. In humans, increased 8-oxoG levels have been observed in various brain regions in Parkinson's disease (Alam et al., 1997; Shimura-Miura et al., 1999) and Alzheimer's disease (Wang et al., 2005). Similarly,
8-oxoG immunoreactivity is increased in many large motor neurons in amyotrophic lateral sclerosis (Kikuchi et al., 2002). Whether oxidative DNA damage in adults contributes to the pathogenesis of human neurodegenerative diseases, or is an outcome of oxidative stress resulting from tissue destruction, is unclear.

In summary, this study corroborates and extends our previous evidence that METH-initiated neurodevelopmental deficits in the fetus and neurodegeneration in adults involve different mechanisms. More importantly, these results provide the most direct evidence to date that 8-oxoG is a developmentally pathogenic molecular lesion, and are the first to show that functional repair of oxidative DNA damage is important in protecting the fetus from METH teratogenicity. Elevated rates of 8-oxoG repair observed in fetal tissue compared with adults, coupled with the total lack of 8-oxoG repair observed in ogg1 knock-out mice, suggest a critical role for OGG1 in protecting the fetus from genotoxic in utero oxidative stress. Interindividual variability in the repair of oxidative DNA damage may contribute to the risk of neurodevelopmental deficits after METH exposure, as well as after enhanced developmental oxidative stress attributable either to endogenous causes or exposure to other ROS-initiating xenobiotics.

\section{References}

Agrawal HC, Glisson SN, Himwich WA (1968) Developmental changes in monoamines of mouse brain. Int J Neuropharmacol 7:97-101.

Alam ZI, Jenner A, Daniel SE, Lees AJ, Cairns N, Marsden CD, Jenner P, Halliwell B (1997) Oxidative DNA damage in the parkinsonian brain: an apparent selective increase in 8-hydroxyguanine levels in substantia nigra. J Neurochem 69:1196-1203.

Alhava E (1972) Amphetamine toxicity in adult and developing mice. Acta Pharmacol Toxicol (Copenh) 31:387-400.

Alhava E (1975) Body temperature responses induced by amphetamine isomers in adult and developing mice. Acta Pharmacol Toxicol (Copenh) 36:465-468.

Alhava E, Klinge E (1972) Age and brain catecholamine content as factors influencing amphetamine toxicity in mice. Acta Pharmacol Toxicol (Copenh) 31:401-411.

Bhuller Y, Wells PG (2006) A developmental role for ataxia-telangiectasia mutated in protecting the embryo from spontaneous and phenytoinenhanced embryopathies in culture. Toxicol Sci 93:156-163.

Bhuller Y, Jeng W, Wells PG (2006) Variable in vivo embryoprotective role for ataxia-telangiectasia-mutated against constitutive and phenytoinenhanced oxidative stress in atm knockout mice. Toxicol Sci 93:146-155.

Bost RO, Kemp P, Hnilica V (1989) Tissue distribution of methamphetamine and amphetamine in premature infants. J Anal Toxicol 13:300-302.

Bowyer JF (2000) Neuronal degeneration in the limbic system of weanling rats exposed to saline, hyperthermia or d-amphetamine. Brain Res 885:166-171.

Bowyer JF, Holson RR (1995) Methamphetamine and amphetamine neurotoxicity. In: Handbook of neurotoxicology (Chang LW, Dyer RS, eds), pp 845-870. New York: Marcel Dekker.

Bowyer JF, Davies DL, Schmued L, Broening HW, Newport GD, Slikker W Jr, Holson RR (1994) Further studies of the role of hyperthermia in methamphetamine neurotoxicity. J Pharmacol Exp Ther 268:1571-1580.

Cadet JL, Brannock C (1998) Free radicals and the pathobiology of brain dopamine systems. Neurochem Int 32:117-131.

Cadet JL, McCoy MT, Ladenheim B (2002) Distinct gene expression signatures in the striata of wild-type and heterozygous c-fos knockout mice following methamphetamine administration: evidence from cDNA array analyses. Synapse 44:211-226.

Cadet JL, Jayanthi S, Deng X (2003) Speed kills: cellular and molecular bases of methamphetamine-induced nerve terminal degeneration and neuronal apoptosis. FASEB J 17:1775-1788.

Cappon GD, Morford LL, Vorhees CV (1997) Ontogeny of methamphetamine-induced neurotoxicity and associated hyperthermic response. Brain Res Dev Brain Res 103:155-162. 
Cardozo-Pelaez F, Brooks PJ, Stedeford T, Song S, Sanchez-Ramos J (2000) DNA damage, repair, and antioxidant systems in brain regions: a correlative study. Free Radic Biol Med 28:779-785.

Chang L, Smith LM, LoPresti C, Yonekura ML, Kuo J, Walot I, Ernst T (2004) Smaller subcortical volumes and cognitive deficits in children with prenatal methamphetamine exposure. Psychiatry Res 132:95-106.

Charlet-Berguerand N, Feuerhahn S, Kong SE, Ziserman H, Conaway JW, Conaway R, Egly JM (2006) RNA polymerase II bypass of oxidative DNA damage is regulated by transcription elongation factors. EMBO J 25:5481-5491.

Chen D, Cao G, Hastings T, Feng Y, Pei W, O’Horo C, Chen J (2002) Agedependent decline of DNA repair activity for oxidative lesions in rat brain mitochondria. J Neurochem 81:1273-1284.

Englander EW, Ma H (2006) Differential modulation of base excision repair activities during brain ontogeny: implications for repair of transcribed DNA. Mech Ageing Dev 127:64-69.

Hailer-Morrison MK, Kotler JM, Martin BD, Sugden KD (2003) Oxidized guanine lesions as modulators of gene transcription. Altered p50 binding affinity and repair shielding by 7,8-dihydro-8-oxo-2' -deoxyguanosine lesions in the NF-kappaB promoter element. Biochemistry 42:9761-9770.

Jeng W, Wong AW, Ting-A-Kee A, Wells PG (2005) Methamphetamineenhanced embryonic oxidative DNA damage and neurodevelopmental deficits. Free Radic Biol Med 39:317-326.

Jeng W, Ramkissoon A, Parman T, Wells PG (2006) Prostaglandin H synthase-catalyzed bioactivation of amphetamines to free radical intermediates that cause CNS regional DNA oxidation and nerve terminal degeneration. FASEB J 20:638-650.

Kathe SD, Shen GP, Wallace SS (2004) Single-stranded breaks in DNA but not oxidative DNA base damages block transcriptional elongation by RNA polymerase II in HeLa cell nuclear extracts. J Biol Chem 279:18511-18520.

Kikuchi H, Furuta A, Nishioka K, Suzuki SO, Nakabeppu Y, Iwaki T (2002) Impairment of mitochondrial DNA repair enzymes against accumulation of 8-oxo-guanine in the spinal motor neurons of amyotrophic lateral sclerosis. Acta Neuropathol 103:408-414.

Klungland A, Rosewell I, Hollenbach S, Larsen E, Daly G, Epe B, Seeberg E, Lindahl T, Barnes DE (1999) Accumulation of premutagenic DNA lesions in mice defective in removal of oxidative base damage. Proc Natl Acad Sci U S A 96:13300-13305.

Laposa RR, Henderson JT, Xu E, Wells PG (2004) Atm-null mice exhibit enhanced radiation-induced birth defects and a hybrid form of embryonic programmed cell death indicating a teratological suppressor function for ATM. FASEB J 18:896-898.

Larsen E, Reite K, Nesse G, Gran C, Seeberg E, Klungland A (2006) Repair and mutagenesis at oxidized DNA lesions in the developing brain of wildtype and Ogg 1-/ - mice. Oncogene 25:2425-2432.

Lee KA, Bindereif A, Green MR (1988) A small-scale procedure for preparation of nuclear extracts that support efficient transcription and premRNA splicing. Gene Anal Tech 5:22-31.

Liu L, Wells PG (1995) DNA oxidation as a potential molecular mechanism mediating drug-induced birth defects: phenytoin and structurally related teratogens initiate the formation of 8-hydroxy-2'-deoxyguanosine in vitro and in vivo in murine maternal hepatic and embryonic tissues. Free Radic Biol Med 19:639-648.

Markwell MA, Haas SM, Tolbert NE, Bieber LL (1981) Protein determination in membrane and lipoprotein samples: manual and automated procedures. Methods Enzymol 72:296-303.

Martin SM, Malkinson TJ, Veale WL, Pittman QJ (1995) Fever in pregnant, parturient, and lactating rats. Am J Physiol 268:R919-R923.

Moallem SA, Hales BF (1998) The role of p53 and cell death by apoptosis and necrosis in 4-hydroperoxycyclophosphamide-induced limb malformations. Development 125:3225-3234.

National Institute on Drug Abuse Research Report Series (2002) Methamphetamine abuse and addiction. Available at: http://www.nida. nih.gov/ResearchReports/methamph/methamph.html.
Nishioka K, Ohtsubo T, Oda H, Fujiwara T, Kang D, Sugimachi K, Nakabeppu Y (1999) Expression and differential intracellular localization of two major forms of human 8-oxoguanine DNA glycosylase encoded by alternatively spliced OGG1 mRNAs. Mol Biol Cell 10:1637-1652.

Olshan AF, Shaw GM, Millikan RC, Laurent C, Finnell RH (2005) Polymorphisms in DNA repair genes as risk factors for spina bifida and orofacial clefts. Am J Med Genet A 135:268-273.

Pastoriza-Gallego M, Armier J, Sarasin A (2007) Transcription through 8-oxoguanine in DNA repair-proficient and Csb(-)/Ogg1(-) DNA repairdeficient mouse embryonic fibroblasts is dependent upon promoter strength and sequence context. Mutagenesis 22:343-351.

Plessinger MA (1998) Prenatal exposure to amphetamines. Risks and adverse outcomes in pregnancy. Obstet Gynecol Clin North Am 25:119-138.

Pu C, Vorhees CV (1993) Developmental dissociation of methamphetamine-induced depletion of dopaminergic terminals and astrocyte reaction in rat striatum. Brain Res Dev Brain Res 72:325-328.

Riis B, Risom L, Loft S, Poulsen HE (2002) OGG1 mRNA expression and incision activity in rats are higher in foetal tissue than in adult liver tissue while 8-oxo-2'-deoxyguanosine levels are unchanged. DNA Repair (Amst) 1:709-717.

Rosenquist TA, Zaika E, Fernandes AS, Zharkov DO, Miller H, Grollman AP (2003) The novel DNA glycosylase, NEIL1, protects mammalian cells from radiation-mediated cell death. DNA Repair (Amst) 2:581-591.

Shibutani S, Grollman AP (1994) Miscoding during DNA synthesis on damaged DNA templates catalysed by mammalian cell extracts. Cancer Lett 83:315-322.

Shimura-Miura H, Hattori N, Kang D, Miyako K, Nakabeppu Y, Mizuno Y (1999) Increased 8-oxo-dGTPase in the mitochondria of substantia nigral neurons in Parkinson's disease. Ann Neurol 46:920-924.

Spencer SJ, Mouihate A, Galic MA, Pittman QJ (2008) Central and peripheral neuroimmune responses: hyporesponsiveness during pregnancy. J Physiol 586:399-406.

Verjat T, Dhénaut A, Radicella JP, Araneda S (2000) Detection of 8-oxoG DNA glycosylase activity and OGG1 transcripts in the rat CNS. Mutat Res 460:127-138.

Viswanathan A, Doetsch PW (1998) Effects of nonbulky DNA base damages on Escherichia coli RNA polymerase-mediated elongation and promoter clearance. J Biol Chem 273:21276-21281.

Viswanathan A, You HJ, Doetsch PW (1999) Phenotypic change caused by transcriptional bypass of uracil in nondividing cells. Science 284:159-162.

Wang J, Xiong S, Xie C, Markesbery WR, Lovell MA (2005) Increased oxidative damage in nuclear and mitochondrial DNA in Alzheimer's disease. J Neurochem 93:953-962.

Wells PG, Winn LM (1996) Biochemical toxicology of chemical teratogenesis. Crit Rev Biochem Mol Biol 31:1-40.

Wells PG, Kim PM, Laposa RR, Nicol CJ, Parman T, Winn LM (1997) Oxidative damage in chemical teratogenesis. Mutat Res 396:65-78.

Wells PG, Bhuller Y, Chen CS, Jeng W, Kasapinovic S, Kennedy JC, Kim PM, Laposa RR, McCallum GP, Nicol CJ, Parman T, Wiley MJ, Wong AW (2005) Molecular and biochemical mechanisms in teratogenesis involving reactive oxygen species. Toxicol Appl Pharmacol 207[2 Suppl]:354-366.

Won L, Bubula N, McCoy H, Heller A (2001) Methamphetamine concentrations in fetal and maternal brain following prenatal exposure. Neurotoxicol Teratol 23:349-354.

Wong AW, Wells PG (2006) The role of oxidative DNA damage and repair in methamphetamine-initiated neurodevelopmental deficits. Toxicol Sci [Supplement: The Toxocologist] 90:293.

Wong AW, Jeng W, Wells PG (2004) Methamphetamine-initiated neurodevelopmental deficits are enhanced in oxoguanine glycosylase 1 (ogg1) knock-out mice. Toxicol Sci [Supplement: The Toxocologist] 78:379. 